\title{
Mechanisms of Horizontal Gene Transfer
}

\author{
Fabio Cafini, Veronica Medrano Romero and \\ Kazuya Morikawa
}

Additional information is available at the end of the chapter

http://dx.doi.org/10.5772/65967

\begin{abstract}
Horizontal gene transfer plays important roles in the evolution of S. aureus, and indeed, a variety of virulence factors and antibiotic resistance genes are embedded in a series of mobile genetic elements. In this chapter, we review the mechanisms of horizontal gene transfer, including recent findings on the natural genetic competence. Then, we consider the transfer of two important antibiotic resistance genes: the methicillin resistance gene, mecA (in Staphylococcal Cassette Chromosome) and the linezolid resistance gene, cfr (in plasmid). In either case, distinct mechanisms driving the gene dissemination support the prominent evolutionary ability of this important human pathogen.
\end{abstract}

Keywords: Transduction, Conjugation, Transformation, staphylococcal cassette chromosome (SCC), cfr

\section{Introduction}

Staphylococcus aureus is an opportunistic pathogen responsible for diverse infectious diseases ranging from food poisoning and superficial skin abscesses to more serious infections such as pneumonia, meningitis, osteomyelitis, septicemia, endocarditis and toxic shock syndrome. The resistance to a wide variety of antibiotics [1,2] is a global concern in clinical settings, and methicillin-resistant strains (MRSA), the most common cause of nosocomial infections, are now spreading into the community [3]. The emergence and dissemination of further resistant strains such as vancomycin-resistant S. aureus (VRSA) [4] and linezolid-resistant S. aureus (LRSA) [5, 6] are anticipated. Major parts of staphylococcal virulence and antibiotics resistance are acquired characteristics, evidenced by many of the toxin and antibiotic resistance genes embedded in mobile genetic elements such as transposons, bacteriophages, insertion 
sequences, pathogenicity islands and the staphylococcal cassette chromosome (SCC) [7, 8]. In this chapter, we review the current understanding about horizontal gene transfer (HGT) in S. aureus including the recently discovered natural transformation. We also discuss how two important mobile genetic elements (SCC and cfr plasmid) would be transferred from cell to cell.

\section{Horizontal gene transfer mechanisms}

\subsection{Phage-related mechanisms}

Phage-mediated horizontal gene transfer is the major driving force for $S$. aureus evolution and is well reviewed elsewhere [9]. The experimental protocols for the phage transduction are also established [10]. Staphylococcal phages can also serve as a helper phage to transfer Staphylococcus aureus pathogenicity islands (SaPIs) [11]. SaPI carries toxin genes including the toxic shock syndrome toxin 1 and superantigens. In addition to the conventional transduction by staphylococcal phages, atypical giant phage in environment is also capable of transduction [12].

In 1970s, a transformation-like phenomenon (now termed "pseudo-competence" or "pseudotransformation") was described [13]. A series of studies have confirmed that it is a HGT mechanism that requires the presence of a staphylococcal phage [14]. The "competence-conferring factor" was most likely the phage tail that has lytic activity. In some old bacteriology books, pseudo-competence is regarded as competence, but the first report on genuine natural genetic competence was published on 2012 [15]. Pseudo-competence was demonstrated to be distinct from natural competence: the important competence genes encoded in the com $G$ and comE operons were dispensable for pseudo-competence [15].

\subsection{Conjugation}

Bacterial conjugation has been studied in Gram-negative and Gram-positive species. Although broad-host-range plasmids able to replicate in both groups exist, the differences in terms of membrane and peptidoglycan cell wall require different conjugation systems on the basis of cell-to-cell recognition and contact.

Most of the conjugative staphylococcal plasmids studied belong to the incQ family. One of the better known staphylococcal conjugative plasmid is pGO1 [16], considered as the prototype of this type of plasmids. All the conjugative genes are located on a $14.5 \mathrm{~kb}$ region, and the minimal machinery necessary for conjugation includes the oriT, a nickase protein (nes) and the tra operon. This plasmid shows high similarities, in terms of genetic organization of the tra operon, with other Gram-positive conjugative plasmids such as the staphylococcal pSK41 plasmid [17], the lactococcal pMRC01 [18] and the enterococcal pRE25 [19].

Staphylococcal plasmids related to the pGO1/pSK41 family share an important homology regarding the organization of conjugative genes and, in addition, present an identical IncQ-type 
relaxase and a nickase gene (nes) responsible for the generation of the nick at the oriT [17]. The plasmids belonging to this family are self-conjugative, and they are able to mobilize small non-conjugative coresident plasmids. They are also associated with gentamicin (and other aminoglycosides) resistance and can be related to resistance to penicillin, trimethoprim, bleomycin, tetracycline, macrolides, lincosamide, streptogramin B and antiseptics [20]. These plasmids have contributed to the evolution of staphylococcal species in antibiotic-enriched environments, and recently, they have been reported to be related to resistance against the most important antimicrobials used in MRSA treatment: linezolid and vancomycin.

\subsection{Natural transformation}

Natural transformation requires the uptake of environmental DNA by the action of a set of DNA-uptake proteins that are expressed in the bacterial membrane. Once DNA is incorporated into the cytoplasm, it can be used as a source of nutrients, as a template to repair damaged genetic material or to enhance bacterial fitness by generating diversity or introducing novel traits [21].

To undergo transformation, bacteria need to develop a specific physiological state called genetic competence. Competence is achieved through the regulated expression of the genes encoding the DNA uptake machinery [22]. In general, Gram-positive DNA uptake machinery is formed by a pseudopilus (ComG proteins) that brings extracellular DNA to the cytoplasmic transport machinery, a DNA-binding protein (the receptor ComEA) and a channel (ComEC). Only a single strand enters the cytosol, while the complementary strand is degraded by an endonuclease [23].

S. aureus had been regarded as a non-transformable species until natural transformation was demonstrated in 2012 [15]. Natural transformation can transfer long DNA fragments that are too large to be transferred by bacteriophages (transduction) [22]. Indeed, the long staphylococcal cassette chromosome mec (SCCmec) type II element was successfully transferred by transformation [15], leading to the idea that the exchange of large DNA regions between distinct $S$. aureus clonal complexes may be also due to the natural transformation [24].

The regulation of competence development is a species-specific process. In S. aureus, the main competence regulator is the alternative sigma factor $\mathrm{H}(\mathrm{SigH})$. SigH activates the transcription of the competence machinery genes (com $G$ and comE operons) that are essential for the development of natural transformation $[15,25]$. In addition, the transcription factor ComK enhances the expression of the SigH regulon [26]. SigH is expressed in a minor population by two distinct mechanisms. The sigH gene can be rearranged by a "short-junction duplication," or be post-transcriptionally regulated through an inverted repeat (IR) sequence at the $5^{\prime}$-UTR of sigH mRNA. The IR is thought to hinder the ribosome-binding site to suppress the SigH expression, but the activation mechanism is not clarified yet.

Competence development is a species-specific process that requires particular environmental conditions. These conditions include nutrient access, starvation, altered growth conditions and cell density [22]. Natural transformation in S. aureus is detectable under specific conditions 
when cells are grown in the chemically defined CS2 medium [15]. Under these growth conditions, wild-type strains (N315 and its derivative) show low transformation frequencies $\left(<10^{-11}\right)$, partly attributed to the subpopulation limited SigH expression. Overexpression of SigH increases the transformation frequencies up to $\sim 10^{-9}$ when purified plasmid DNA is used as donor and to $\sim 10^{-7}$ if living S. aureus COL cells carrying pT181 are used. Moreover, there seems to be more preferable growth conditions that facilitate transformation (Ohniwa et al., in preparation). So far, we achieved c.a. $10^{-6}$ level frequency in the unmodified N315 derivative strains, as well as in a part of the clinical isolates, which will be published elsewhere.

Even in SigH-expressing cells, the transformation frequencies change depending on the growth conditions, suggesting that there are additional levels of regulations for an efficient transformation. Importantly, antimicrobial agents also affect the transformation efficiencies in the SigH-expressing cells [27]. Table 1 summarizes the effect of the antibiotics in S. aureus and other species. Table 1 also includes the SOS response, because it is a complementary response in some bacteria: antibiotics that induce SOS response, such as fluoroquinolone or mitomycin C, induce competence in species lacking the SOS system [28-30] but suppress competence in species harboring the SOS system [31]. Although SOS response in $S$. aureus is limited and its accessories are simple, it does exist $[32,33]$. The treatment with mitomycin C suppresses transformation in S. aureus. However, ciprofloxacin (fluoroquinolone) has no effect. This might indicate that the interplay between natural transformation and SOS response cannot be simplified. S. aureus response to $\beta$-lactam antibiotics is also linked to SOS response [34-36]. Fosfomycin and vancomycin increase natural transformation in SigH-expressing cells, but the detailed response mechanism involved is not known. Whether these inducing effects can be observed in the unmodified strains needs to be tested in a future study.

\begin{tabular}{|c|c|c|c|c|c|c|c|c|}
\hline & & \multicolumn{2}{|c|}{ S. aureus (+ SigH cells) } & \multicolumn{2}{|c|}{ S. thermophilus } & \multirow{2}{*}{$\begin{array}{l}\text { S. } \mathrm{p}^{*} \\
\mathrm{TF}^{* *}\end{array}$} & \multirow{2}{*}{$\begin{array}{l}\text { L. } \mathrm{p}^{*} \\
\text { TF }^{* *}\end{array}$} & \multirow{2}{*}{$\begin{array}{l}\text { H. } \mathbf{p}^{*} \\
\mathrm{TF}^{* *}\end{array}$} \\
\hline & & $\mathrm{TF}^{* *}$ & sos & $\mathrm{TF}^{* *}$ & sos & & & \\
\hline & Fosfomycin & $+[27]$ & & & & & & \\
\hline & Vancomycin & $+[27]$ & & & & \multicolumn{2}{|l|}{ No effect [28] } & \\
\hline & Oxacillin & - [27] & Yes $[34,35]$ & & & & & \\
\hline & Cefazolin & - [27] & & & & & & \\
\hline & Ampicillin & & Yes [36] & & & No effect [28] & No effect [29] & $\begin{array}{l}\text { No effect } \\
{[30]}\end{array}$ \\
\hline \multirow[t]{3}{*}{ Quinolones } & Ciprofloxacin & No effect [27] & Yes [32] [37] & & & & & $+[30]$ \\
\hline & Norfloxacin & & & $-[31]$ & Yes [31] & $+[28]$ & $+[29]$ & \\
\hline & Mitomycin C & $-[27]$ & Yes [37] [38] & $-[31]$ & Yes [31] & $+[28]$ & & \\
\hline $\begin{array}{l}{ }^{*} \text { S. p, L. p, H } \\
{ }^{* *} \text { TF: transfo } \\
\text { S. p: Streptoc }\end{array}$ & $\begin{array}{l}\text { H. p lack SOS sy } \\
\text { ormation and/or } \\
\text { coccus pneumoni }\end{array}$ & $\begin{array}{l}\text { stem }[29,33] \text {. } \\
\text { r competence g } \\
\text { iae, L. p: Legione }\end{array}$ & $\begin{array}{l}\text { ene express } \\
\text { lla pneumop }\end{array}$ & & bacte & & & \\
\hline
\end{tabular}

Table 1. Effects of antibiotics on transformation and SOS response. 


\section{Dissemination of antibiotic resistance determinants}

Since Fleming's discovery of penicillin and its application to treatment, S. aureus has experienced a variety of antibiotics in clinical settings. Penicillin-resistant $S$. aureus was described before the introduction of penicillin to the market in 1943. It carried a $\beta$-lactamase gene in a plasmid. Methicillin was developed as a $\beta$-lactam derivative that cannot be degraded by $\beta$-lactamase, but methicillin-resistant $S$. aureus (MRSA) was described soon after its introduction. The methicillin resistance gene is in a mobile genetic element designated staphylococcal cassette chromosome (SCC). Vancomycin is one of the effective resources for MRSA treatment, though vancomycin-resistant $S$. aureus (VRSA) has already been reported [39]. Linezolid is another promising anti-MRSA drug, but the dissemination of linezolid resistance is also anticipated. The antibiotic resistance genes and a series of reports on their transfer mechanisms are summarized in Table 2. Here, we focus on the dissemination mechanisms of SCC and linezolid resistance.

\subsection{Dissemination of SCC}

$\beta$-lactams were the first line of antibiotics against $S$. aureus infections. However, resistance has rapidly emerged. The first methicillin-resistant S. aureus (MRSA) strain was identified in 1961, only one year after the clinical introduction of methicillin [76]. Methicillin is a semisynthetic penicillin that resists the action of $\beta$-lactamases. It was introduced as a first choice treatment against infections caused by penicillin-resistant $S$. aureus. The methicillin resistance gene $(m e c A)$ encodes an alternative penicillin-binding protein (PBP2a) that has low affinity for all $\beta$-lactams. PBP2a can maintain the cell wall synthesis, while all the other PBPs are inhibited by $\beta$-lactams [77].

The mecA gene is carried in a variable mobile element called staphylococcal cassette chromosome mec (SCCmec). SCCmec is integrated in a unique orientation into a specific chromosomal attachment site (attBSCC) [78]. The basic structure of the SCCmec element consists of a cassette chromosome recombinase (ccr) and a mec complex. The mec complex contains the mecA gene and its regulatory genes (not always present) [79]. The cassette is classified according to a combination of both complexes [80]. The International Working Group on the Staphylococcal Cassette Chromosome elements reports 11 types of SCCmec (http://www.sccmec.org/Pages/ SCC_TypesEN.html). SCCmec varies in size (from 20 to $67 \mathrm{~kb}$ ), and it can carry other elements such as resistance genes, insertion elements, plasmids or transposons. SCCmec elements have only been found in staphylococci with the exception of Macrococcus caseolyticus [43]. This species is closely related to the staphylococci, and it was part of the Staphylococcus genus until 1998 when it was reclassified [81].

MRSA strains appeared in the hospital environment and spread rapidly causing serious clinical problems and several hospital outbreaks. The first MRSA strain was identified in the United Kingdom in 1961, and it carried the type I SCCmec. Types II and III were identified in the early 1980s in Japan and New Zealand, respectively. These types of SCCmec were all identified in the hospital environment; they are the largest types and can carry additional 


\begin{tabular}{|c|c|c|c|c|c|c|}
\hline Type & Antibiotic & Gene & Location & Origin & $\begin{array}{l}\text { Reported/probable } \\
\text { HGT mechanism }\end{array}$ & Refs. \\
\hline \multirow[t]{2}{*}{$\beta$-lactams } & Penicillin & blaZ & $\begin{array}{l}\text { Plasmid } \\
\text { (transposon) }\end{array}$ & $\begin{array}{l}\text { S. } \\
\text { haemolyticus? }\end{array}$ & $\begin{array}{l}\text { Conjugation } \\
\text { Pseudo- } \\
\text { transformation }\end{array}$ & [40-42] \\
\hline & Methicillin & mecA & $\begin{array}{l}\text { Chromosome } \\
\text { (SCCmec) }\end{array}$ & CoNS & $\begin{array}{l}\text { Transduction } \\
\text { Conjugation } \\
\text { Transformation }\end{array}$ & $\begin{array}{l}{[15,} \\
43-49]\end{array}$ \\
\hline Glycopeptides & Vancomycin & $\operatorname{van} A$ & $\begin{array}{l}\text { Plasmid } \\
\text { (transposon) }\end{array}$ & $\begin{array}{l}\text { Enterococcus } \\
\text { spp. }\end{array}$ & Conjugation & {$[50,51]$} \\
\hline Aminoglycosides & $\begin{array}{l}\text { Gentamicin } \\
\text { Kanamycin } \\
\text { Tobramycin }\end{array}$ & $a a c A-a p h D$ & $\begin{array}{l}\text { Plasmid } \\
\text { (transposon) }\end{array}$ & Bacillus spp.? & $\begin{array}{l}\text { Conjugation } \\
\text { Transduction }\end{array}$ & {$[52]$} \\
\hline \multirow[t]{3}{*}{ Antifolates } & Trimethoprim & $d f r A$ & $\begin{array}{l}\text { Plasmid } \\
\text { (transposon) }\end{array}$ & Bacillus spp.? & Conjugation & {$[53,54]$} \\
\hline & & $d f r G$ & Chromosome (IS) & E. faecium? & - & {$[55]$} \\
\hline & & $d f r K$ & $\begin{array}{l}\text { Plasmid } \\
\text { Chromosome } \\
\text { (transposon) }\end{array}$ & $?$ & Conjugation & {$[56-58]$} \\
\hline \multirow{3}{*}{$\begin{array}{l}\text { Macrolide } \\
\text { Lincosamide } \\
\text { Streptogramin B }\end{array}$} & & ermB & $\begin{array}{l}\text { Plasmid } \\
\text { (transposon) }\end{array}$ & Streptococci & $\begin{array}{l}\text { Conjugation } \\
\text { Transduction }\end{array}$ & [59-61] \\
\hline & & ermC & Plasmid & CoNS & Transduction & {$[60,62]$} \\
\hline & & ermA & $\begin{array}{l}\text { Chromosome } \\
\text { (transposon) }\end{array}$ & CoNS & Conjugation & $\begin{array}{l}{[60,62,} \\
63]\end{array}$ \\
\hline \multirow[t]{2}{*}{ Tetracyclines } & Tetracycline & tetK tet $L$ & Plasmid & $\begin{array}{l}\text { Streptococci } \\
\text { Enterococci }\end{array}$ & Conjugation & {$[64,65]$} \\
\hline & & tet $M$ & $\begin{array}{l}\text { Chromosome } \\
\text { (transposon) }\end{array}$ & $\begin{array}{l}\text { Streptococci } \\
\text { E. faecalis }\end{array}$ & Conjugation & {$[61,64]$} \\
\hline Chloramphenicol & Chloramphenicol & cat & Plasmid & S. epidermidis & $\begin{array}{l}\text { Conjugation } \\
\text { Transduction }\end{array}$ & $\begin{array}{l}{[8,66,} \\
67]\end{array}$ \\
\hline Oxazolidinones & Lynezolid & $c f r$ & Plasmid & CoNS? & $\begin{array}{l}\text { Conjugation } \\
\text { Transduction }\end{array}$ & [6] \\
\hline Streptogramins & Dalfopristin & $\begin{array}{l}\text { vgaA, vgaB, } \\
\text { vat } A, \text { vat } B \\
\text { vat } C\end{array}$ & Plasmid & $?$ & Conjugation & {$[68,69]$} \\
\hline \multirow[t]{2}{*}{ Fusidanes } & Fusidic acid & fusB & $\begin{array}{l}\text { Chromosome } \\
\text { (SaPI) } \\
\text { Plasmid }\end{array}$ & CoNS & Transduction & {$[11,70]$} \\
\hline & & fusC & $\begin{array}{l}\text { Chromosome } \\
\text { (SCC) }\end{array}$ & CoNS & - & $\begin{array}{l}{[7} \\
-75]\end{array}$ \\
\hline Phosphonic acids & Fosfomycin & fos $B$ & $\begin{array}{l}\text { Chromosome } \\
\text { (SaPI) }\end{array}$ & $?$ & Transduction & [11] \\
\hline
\end{tabular}

Table 2. Antibiotics resistance genes. 
resistance elements; strains that carry them are usually multi-resistant [78, 82]. During the 1990s, community-associated MRSA strains were identified, and during the early 2000s, the SCCmec type IV and V were described in USA and Australia, respectively. These types are smaller elements that rarely carry extra resistance elements, and they are described as community-associated SCCmec types [83, 84]. Types I to V are the main and widely distributed elements; since their description, new variants have been reported (SCCmec VI-XI).

The origin of the SCCmec element is not clear, but evidence indicates that it comes from coagulase negative staphylococci (CoNS). Ancestral forms have been identified in S. sciuri, S. fleuretti, S. xylosus, S. hominis and M. caseolyticus [43-45]. The source of the mec and ccr complex is unknown, but they may have assembled into SCCmec in CoNS where they were modified and then transferred to S. aureus [46]. The primary source of SCCmec for S. aureus seems to be $S$. epidermidis. SCCmec type IV shares high homology between both species [85]; S. haemolyticus and S. hominis appear to be reservoirs for specific classes of mec complex and ccr genes [86, 87].

The transfer mechanism of SCCmec is not well defined. Successful transfer via transduction, conjugation and natural transformation has been reported. Although transduction of small SCCmec elements (type IV, I and V) has been described $[47,48]$, it is unlikely that this is the predominant method. Many of the SCCmec are too big (up to $\sim 60 \mathrm{~kb}$ ) to be encapsulated by a phage. Conjugation is an alternative mechanism. Ray et al. demonstrated the transfer of a $30.8 \mathrm{~kb}$ element (modified from SCCmec II) via conjugation, the spontaneous excision from the conjugative plasmid and the insertion into the recipient chromosome of $S$. aureus and S. epidermidis [49]. However, these authors induced the transfer by overproducing ccr $A B$. Natural transformation can also explain the transfer of large SCCmec types. We have successfully transferred the SCCmec II [15]. However, the interspecies transfer by natural transformation has not been tested.

\subsection{Dissemination of $c f r$}

The $c f r$ gene was identified in 2000; it was described as a new chloramphenicol/florfenicol resistance element located on the pSCFS1 plasmid [88]. This plasmid was the first multi-resistance plasmid found in a Staphylococcus sciuri (isolate from the nasal swab of a calf) and was associated with resistance to chloramphenicol, florfenicol, spectinomycin and MLSB (macrolide, lincosamide and streptogramin B) antibiotics. The cfr gene was associated with the tn558 transposon, closely related to the tn554 associated with erythromycin resistance [89].

The $c f r$ gene was not associated with clinical cases until 2007, when it was demonstrated that this gene was responsible for the elevated MIC to linezolid in one clinical MRSA strain isolated in Medellin (Colombia) [90]. Linezolid is a synthetic inhibitor of protein synthesis. Its activity against Gram-positive bacteria (including MRSA and Enterococcus sp., even in the case of reduced vancomycin susceptibility) made this antibiotic an essential tool in the treatment of resistant pathogens [91].

Up to 2007, the only known mechanism for linezolid resistance known in staphylococci was the spontaneous mutations in ribosomal proteins [92]. This non-transmissible mechanism 
was associated with the previous intensive use of linezolid. The association of a potential transmissible mechanism of resistance to this antibiotic represented a global concern due to the scarce alternatives for the infections caused by these pathogens and also, due to the potential spreading of this resistance mechanism to the pathogenic bacterial pool.

When the first cfr-positive clinical isolate was detected, sequencing analysis showed the absence of any mutation previously associated with linezolid resistance. The strains showed an unexpected post-transcriptional modification at A2503 in the 23S rRNA. The mechanism underlying the resistance conferred by cfr is related to the modification of the antibiotic target site on the 23S ribosomal RNA [90]. Thus, cfr is a methyltransferase that causes a reduced ribose methylation at C2498 and the addition of an extra methylation at A2503.

In 2008, the first outbreak of linezolid-resistant MRSA strain was reported in Spain [93]. The outbreak took place in the intensive care unit (ICU) of a public hospital and lasted 3 months. A total of 15 patients infected or colonized with linezolid-resistant MRSA were detected. In this case, some isolates showed identical PFGE profiles, showing the clonal dissemination of the same linezolid-resistant strain, but other $c f r$-positive strains showed a different PFGE profile. As cfr prevalence was extremely low, the existence of a horizontal gene transfer event was strongly suggested, and specially, the potential existence of some undetected reservoir, capable of spreading the $c f r$ gene among the pathogenic staphylococcal pool, was hypothesized. The association of a potentially transmissible mechanism of resistance to this antibiotic represented a global concern due to the scarce treatment alternatives and the potential spreading to the pathogenic bacterial pool.

In 2008, the presence of plasmid-borne cfr in two strains isolated in Ohio hospitals was described [94]. In this case, two staphylococci, one MRSA and one S. epidermidis, with linezolid MICs of 8 and $256 \mathrm{mg} / \mathrm{L}$, respectively, were isolated from two different patients. Sequence analysis found two different plasmids on the basis of the cfr insertion context. The S. epidermidis insertion couldn't be determined, but the plasmid harbored by the $S$. aureus strain showed a pSCFS3-like genetic environment [95]. In this genetic context, the Tn558 transposon was truncated by the tandem insertion of ist AS-istBS, potentially related to $c f r$ gene mobilization. Since 2008 several studies detected the presence of this gene in livestock-associated strains belonging to different bacterial species such as Proteus vulgaris, Enterococcus spp., Macrococcus caseolyticus or Jeotgalicoccus pinnipedialis [96-98]. These findings showed the spread of these resistance traits among livestock-associated bacteria known as reservoir for clinical-associated strains.

In 2010, during the analysis of a collection of Panton-Valentine leukocidin (PVL)-positive MRSA isolates from Ireland, one cfr-positive strain was detected [99]. This strain harbored a ca. $40 \mathrm{kbp}$ plasmid with $c f r$ associated with the Tn558 transposon. However, this gene was located in a genetic context not previously described. In this plasmid, named pSCFS7, cfr gene was found inserted in the $\operatorname{tn} B$ gene reading frame. In this case, this gene was truncated by the insertion of the terminal region of istBS. The detection of the pSCFS7 plasmid was especially relevant; on one hand, the $c f r$-positive MRSA strain belonged to the USA 300 genotype (ST8-MRSA-IVa), which is predominant among community-acquired MRSA 
(CA-MRSA) in the United States [100]. And on the other hand, pSCFS7 plasmid demonstrated the capability to be transferred by conjugation to other S. aureus strains. Thus, this was the first report of a conjugative plasmid on S. aureus strain belonging to genotypes with clinical relevance.

Linezolid susceptibility among clinically significant isolates is monitored by different surveillance programs, such as Zyvox Annual Appraisal of Potency and Spectrum (ZAAPS) and the USA Linezolid Experience and Accurate Determination of Resistance (LEADER). According to the results obtained by these programs, linezolid resistance was $0.05 \%$ for $S$. aureus and 1.4\% for CoNS between 2002 and 2010 [101, 102]. CoNS, not considered as true pathogens, show higher levels of resistance and could act as $c f r$ reservoir for the $S$. aureus pool. In fact, the high incidence of unique clones (40\%) among cfr-positive MRSA suggested that the transmission of the cfr gene by HGT could be a common phenomenon [5].

The impact of the transmission of $c f r$ among potential reservoirs was determined in Spain after the $c f r$-positive MRSA outbreak in the same hospital [103]. In this study, 100 linezolidresistant S. epidermidis strains obtained between 2008 and 2011 were analyzed. Authors did not recover cfr-positive MRSA strains, but they detected this gene in the $58 \%$ of the linezolid-resistant $S$. epidermidis isolates, again suggesting the potential role of CoNS as linezolid resistance reservoirs. In 2012, two geographically independent staphylococci harboring conjugative $c f r$-associated plasmids were detected in Spain. One of them was located on a MRSA belonging to ST125 genotype, prevalent among hospital-associated strains (HAMRSA). This plasmid, named pERGB, showed a new genetic environment of cfr insertion, associated with the istAS-istBS tandem but not with the TN558 transposon [104]. In addition, it also showed the ability to be transferred by conjugation to the ATCC 29213 S. aureus strain.

The second $c f r$-associated vector detected in Spain was found on a ST22 S. epidermidis strain [105]. In this case, $c f r$ was inserted on a genetic environment identical to the pSCFS7 vector and the plasmid also showed an in vitro conjugative transmission. This was the first report of pSCFS7-like plasmids in Spain associated with clinical staphylococci, followed by the finding of two more strains harboring similar vectors in 2014 [106]. Two staphylococcal strains (one Staphylococcus haemolyticus and one S. aureus) obtained from two clinical cases of septic shock were identified in the same hospital in Spain. Both strains harbored similar ca.40 kb conjugative pSCFS7-like vectors. Although plasmid restriction analysis profiles showed small differences between both strains, the emergence of unrelated $c f r$-positive $S$. aureus and CoNS and the presence of this gene in similar pSCFS7-like plasmids in Spain $[105,106]$ suggest the potential spread of these vectors among the staphylococcal pool in Spain.

While the observed situation suggested the spread of pSCFS7 among the staphylococci in Spain, in the USA, the situation regarding the prevalence of $c f r$ vectors was different. In addition to the pSCFS3-like vector described in 2008 [94], cfr-positive strains carrying these plasmids were found in 2013 [107]. The study comprised 19 S. epidermidis and 2 S. aureus linezolid-resistant strains. Among the studied strains, one S. aureus strain did not share a similar plasmid profile. Plasmid sequence analysis demonstrated the existence of identical $39.3 \mathrm{~kb}$ 
pSCFS3-like plasmids in one S. epidermidis and S. aureus isolates [6]. As pSCFS3 plasmids were considered as non-conjugative vectors [94], this indirect demonstration of plasmid transmission questioned the nature of the HGT involved in the spread of these plasmids. In addition, an unexpected result was obtained analyzing the sequence of two cfr plasmids obtained in staphylococcal clinical isolates from German hospitals [108]. In this study, 6 cfr-positive strains were identified among 36 linezolid-resistant S. epidermidis isolated between January 2012 and April 2013. Sequence analysis showed the existence of pSCFS6 and pSCFS7-like plasmids. The pSCFS6-like plasmid showed substantial homology to pGO1 plasmid, meanwhile the pSCFS7, as well as pSCFS3-like plasmids, showed the most significant homology to pSK73 plasmid [107]. The presence of pSCFS7-like plasmids in clinical isolates from Germany may suggest the potential spread of these plasmids among European hospitals. Nevertheless, although pSCFS6 harbored the pGO1 tra and nes conjugative machinery, none of these genes were located in the pSCFS7 sequence, suggesting potential mobilization events of $c f r$ environment onto different plasmids backbones [108].

Although conjugation alone was the recognized transmission mechanism for the $c f r$ gene, the presence of identical putative non-conjugative pSCFS3 plasmids in different staphylococcal species suggested the existence of other HTG mechanisms involved in the spreading of linezolid resistance [107]. Our group answered this question demonstrating an alternative mechanism for $c f r$ spread based on phage transduction among MRSA [6]. By using a S. aureus N315 derivate strain harboring a pSCFS7-like vector obtained by conjugation from one clinical $S$. epidermidis strain, we transferred this gene to other MRSA strains by conjugation as well as transduction. In addition, this transmission allowed transductant MRSA cfr-positive strains to retain the conjugative capability, suggesting the complete transmission of this vector, or at least all the necessary genes to allow conjugative transmission.

\section{Conclusion}

The prominent evolutionary ability of Staphylococcus aureus partly relies on the gene transfer mechanisms ranging from the conventional phage transduction and conjugation to the unique staphylococcal mechanisms such as SaPI-helper phage. Recently found staphylococcal natural transformation further explains the ability to transfer larger genetic elements. The surveillance for antibiotics resistance (especially for the last resort antibiotics such as linezolid and vancomycin) is critical, and the test of emerging resistant pathogens in terms of their ability to use these distinct gene dissemination pathways might help to control the evolution of this important human pathogen.

\section{Acknowledgements}

We thank Ms. Nguyen Thi Le Thuy for her help. We acknowledge the supports from Pfizer Academic Contributions and Takeda Science Foundation. 


\section{Author details}

Fabio Cafini ${ }^{1{ }^{\dagger}}{ }^{+}$, Veronica Medrano Romero ${ }^{2,+}$ and Kazuya Morikawa ${ }^{3 *}$

*Address all correspondence to: morikawa.kazuya.ga@u.tsukuba.ac.jp

1 Universidad Europea de Madrid, Department of Basic Biomedical Science, Madrid, Spain

2 Graduate School of Comprehensive Human Sciences, University of Tsukuba, Tsukuba, Japan

3 Division of Biomedical Science, Faculty of Medicine, University of Tsukuba, Tsukuba, Japan

† These authors contributed equally

\section{References}

[1] Lowy, F.D., Antimicrobial resistance: the example of Staphylococcus aureus. J Clin Invest, 2003. 111(9): p. 1265-73.

[2] Ito, T., et al., Insights on antibiotic resistance of Staphylococcus aureus from its whole genome: genomic island SCC. Drug Resist Updat, 2003. 6(1): p. 41-52.

[3] Chambers, H.F. and F.R. Deleo, Waves of resistance: Staphylococcus aureus in the antibiotic era. Nat Rev Microbiol, 2009. 7(9): p. 629-41.

[4] Mongodin, E., et al., Microarray transcription analysis of clinical Staphylococcus aureus isolates resistant to vancomycin. J Bacteriol, 2003. 185(15): p. 4638-4643.

[5] Gu, B., et al., The emerging problem of linezolid-resistant Staphylococcus. J Antimicrob Chemother, 2013. 68(1): p. 4-11.

[6] Cafini, F., et al., Horizontal gene transmission of the cfr gene to MRSA and Enterococcus: role of Staphylococcus epidermidis as a reservoir and alternative pathway for the spread of linezolid resistance. J Antimicrob Chemother, 2016. 71(3): p. 587-92.

[7] Lindsay, J.A., Genomic variation and evolution of Staphylococcus aureus. Int J Med Microbiol, 2010. 300(2-3): p. 98-103.

[8] Malachowa, N. and F.R. DeLeo, Mobile genetic elements of Staphylococcus aureus. Cell Mol Life Sci, 2010. 67(18): p. 3057-71.

[9] Deghorain, M. and L. Van Melderen, The Staphylococci phages family: an overview. Viruses, 2012. 4(12): p. 3316-35.

[10] McNamara, P.J., Genetic manipulation of Staphylococcus aureus, in Staphylococcus molecular genetics, J.A. Lindsay, Editor. 2008, Caister Academic Press: Norfolk, UK. p. 89-130.

[11] Novick, R.P., G.E. Christie, and J.R. Penades, The phage-related chromosomal islands of Gram-positive bacteria. Nat Rev Microbiol, 2010. 8(8): p. 541-51. 
[12] Uchiyama, J., et al., Intragenus generalized transduction in Staphylococcus spp. by a novel giant phage. ISME J, 2014. 8(9): p. 1949-52.

[13] Pattee, P.A. and D.S. Neveln, Transformation analysis of three linkage groups in Staphylococcus aureus. J Bacteriol, 1975. 124(1): p. 201-11.

[14] Birmingham, V.A. and P.A. Pattee, Genetic transformation in Staphylococcus aureus: isolation and characterization of a competence-conferring factor from bacteriophage 80 alpha lysates. J Bacteriol, 1981. 148(1): p. 301-7.

[15] Morikawa, K., et al., Expression of a cryptic secondary sigma factor gene unveils natural competence for DNA transformation in Staphylococcus aureus. PLoS Pathog, 2012. 8(11): p. e1003003.

[16] Thomas, W.D., Jr. and G.L. Archer, Identification and cloning of the conjugative transfer region of Staphylococcus aureus plasmid pGO1. J Bacteriol, 1989. 171(2): p. 684-91.

[17] Berg, T., et al., Complete nucleotide sequence of pSK41: evolution of staphylococcal conjugative multiresistance plasmids. J Bacteriol, 1998. 180(17): p. 4350-9.

[18] Dougherty, B.A., et al., Sequence and analysis of the $60 \mathrm{~kb}$ conjugative, bacteriocin-producing plasmid pMRC01 from Lactococcus lactis DPC3147. Mol Microbiol, 1998. 29(4): p. 1029-38.

[19] Schwarz, F.V., V. Perreten, and M. Teuber, Sequence of the 50-kb conjugative multiresistance plasmid pRE25 from Enterococcus faecalis RE25. Plasmid, 2001. 46(3): p. 170-87.

[20] Ramsay, J.P., S.M. Kwong, Murphy, R.J.T., Eto, K.Y., Price, K.J., Nguyen, Q.T., O’Brien, F.G., Grubb, W.B., Coombs, G.W. Neville Firth An updated view of plasmid conjugation and mobilization in Staphylococcus. Mob Genet Elements, 2016. 6(4): p. 1-11.

[21] Chen, I., The ins and outs of DNA transfer in bacteria. Science, 2005. 310(5753): p. 1456-60.

[22] Thomas, C.M. and K.M. Nielsen, Mechanisms of, and barriers to, horizontal gene transfer between bacteria. Nat Rev Microbiol, 2005. 3(9): p. 711-21.

[23] Chen, I. and D. Dubnau, DNA uptake during bacterial transformation. Nat Rev Microbiol, 2004. 2(3): p. 241-9.

[24] Lindsay, J.A., Staphylococcus aureus genomics and the impact of horizontal gene transfer. Int J Med Microbiol, 2014. 304(2): p. 103-9.

[25] Morikawa, K., et al., A new staphylococcal sigma factor in the conserved gene cassette: functional significance and implication for the evolutionary processes. Genes Cells, 2003. 8(8): p. 699-712.

[26] Fagerlund, A., P.E. Granum, and L.S. Havarstein, Staphylococcus aureus competence genes: mapping of the SigH, ComK1 and ComK2 regulons by transcriptome sequencing. Mol Microbiol, 2014. 94(3): p. 557-79. 
[27] Thi, Le T.N., V.M. Romero, and K. Morikawa, Cell wall-affecting antibiotics modulate natural transformation in SigH-expressing Staphylococcus aureus. J Antibiot (Tokyo), 2016. 69(6): p. 464-6.

[28] Prudhomme, M., et al., Antibiotic stress induces genetic transformability in the human pathogen Streptococcus pneumoniae. Science (New York, N.Y.), 2006. 313(5783): p. 89-92.

[29] Charpentier, X., et al., Antibiotics and UV radiation induce competence for natural transformation in Legionella pneumophila. J Bacteriol, 2011. 193(5): p. 1114-21.

[30] Dorer, M.S., J. Fero, and N.R. Salama, DNA damage triggers genetic exchange in Helicobacter pylori. PLoS Pathog, 2010. 6(7): p. e1001026.

[31] Boutry, C., et al., SOS response activation and competence development are antagonistic mechanisms in Streptococcus thermophilus. J Bacteriol, 2013. 195(4): p. 696-707.

[32] Cirz, R.T., et al., Complete and SOS-mediated response of Staphylococcus aureus to the antibiotic ciprofloxacin. J Bacteriol, 2007. 189(2): p. 531-9.

[33] Ambur, O.H., et al., Genome dynamics in major bacterial pathogens. FEMS Microbiol Rev, 2009. 33(3): p. 453-70.

[34] Plata, K.B., et al., Targeting of PBP1 by beta-lactams determines recA/SOS response activation in heterogeneous MRSA clinical strains. PLoS One, 2013. 8(4): p. e61083.

[35] Cuirolo, A., K. Plata, and A.E. Rosato, Development of homogeneous expression of resistance in methicillin-resistant Staphylococcus aureus clinical strains is functionally associated with a beta-lactam-mediated SOS response. J Antimicrob Chemother, 2009. 64(1): p. 37-45.

[36] Maiques, E., et al., beta-lactam antibiotics induce the SOS response and horizontal transfer of virulence factors in Staphylococcus aureus. J Bacteriol, 2006. 188(7): p. 2726-9.

[37] Mesak, L.R., V. Miao, and J. Davies, Effects of subinhibitory concentrations of antibiotics on SOS and DNA repair gene expression in Staphylococcus aureus. Antimicrob Agents Chemother, 2008. 52(9): p. 3394-7.

[38] Anderson, K.L., et al., Characterization of the Staphylococcus aureus heat shock, cold shock, stringent, and SOS responses and their effects on log-phase mRNA turnover. J Bacteriol, 2006. 188(19): p. 6739-56.

[39] Kali, A., Antibiotics and bioactive natural products in treatment of methicillin resistant Staphylococcus aureus: a brief review. Pharmacogn Rev, 2015. 9(17): p. 29-34.

[40] Anthonisen, I.L., et al., Organization of the antiseptic resistance gene qacA and Tn552related $\beta$-lactamase genes in multidrug-resistant Staphylococcus haemolyticus strains of animal and human origins. Antimicrob Agents Chemother, 2002. 46(11): p. 3606-3612. 
[41] Novick, R.P., Genetic systems in staphylococci. Methods Enzymol, 1991. 204: p. 587-636.

[42] Lindberg, M., Sjostrom, J., Johansson, T., Transformation of chromosomal and plasmid characters in Staphylococcus aureus. J Bacteriol, 1972. 109(2): p. 844-847.

[43] Tsukubakishita, S., Kuwahara-Arai, K., Baba, T., Hiramatsu, K., Staphylococcal cassette chromosome mec-like element in Macrococcus caseolyticus. Antimicrob Agents Chemother, 2010. 54(4): p. 1469-75.

[44] Tsukubakishita, S., Kuwahara-Arai, K., Sasaki, T., Hiramatsu, K., Origin and molecular evolution of the determinant of methicillin resistance in staphylococci. Antimicrob Agents Chemother, 2010. 54(10): p. 4352-9.

[45] Wu, S., Piscitelli, C., de Lencastre, H., Tomasz, A., Tracking the evolutionary origin of the methicillin resistance gene: cloning and sequencing of a homologue of mecA from a methicillin susceptible strain of Staphylococcus sciuri. Microb Drug Resist, 1996. 2: p. 435-41.

[46] Otto, M., Coagulase-negative staphylococci as reservoirs of genes facilitating MRSA infection. Bioassays, 2013. 35(1): p. 4-11.

[47] Scharn, C., Tenover, F.C., Goering, R.V., Transduction of staphylococcal cassette chromosome mec elements between strains of Staphylococcus aureus. Antimicrob Agents Chemother, 2013. 57(11): p. 5233-8.

[48] Chlebowicz, M., Maslanova, I., Kuntova, L., Grundmann, H., Pantucek, R., Doskar, J., van Dijl, J.M, The Staphylococcal Cassette Chromosome mec type V from Staphylococcus aureus ST398 is packaged into bacteriophage capsids. Int J Med Microbiol, 2014. 304(56): p. 764-74.

[49] Ray, M., Boundy, S., Archer, G.L., Transfer of the methicillin resistance genomic island among staphylococci by conjugation. Mol Microbiol, 2016. 100(4): p. 675-85.

[50] Noble, W.C., Virani, Z., Cree R.G.A., Co-transfer of vancomycin and other resistance genes from Enterococcus faecalis NCTC 12201 to Staphylococcus aureus. FEMS Microbiol Lett, 1992. 93: p. 195-8.

[51] Sievert, D.M., M.L. Boulton, G. Stolman, D. Johnson, M.G. Stobierski, F.P. Downes, P.A. Somsel, J.T. Rudrik, W. Brown, W. Hafeez, T. Lundstrom, E. Flanagan, R. Johnson, J. Mitchel, S. Chang, Staphylococcus aureus resistant to vancomycin. MMWR Morb Mortal Wkly Rep, 2002. 51: p. 565-7.

[52] Rouch, D.A., Byrne, M.E., Kong, Y.C., Skurray, R.A., The aacA-aphD gentamicin and kanamycin resistance determinant of TN4001 from Staphylococcus aureus: expression and nucleotide sequence analysis. J Gen Microbiol, 1987. 133: p. 3039-52.

[53] Rouch, D.A., Messerotti, L.J., Loo, L.S.L., Jackson, C.A., Skurray, R.A., Trimethroprim resistance transposon Tn4003 from Staphylococcus aureus encodes genes for a dihydrofolate reductase and thymidylate synthetase flanked by three copies of IS257. Mol Microbiol, 1989. 3(2): p. 161-75. 
[54] Archer, G.L., Coughter, J.P., Johnston J.L, Plasmid-encoded trimethoprim resistance in Staphylococci. Antimicrob Agents Chemother, 1986. 29(5): p. 733-40.

[55] Sekiguchi, J., et al., Cloning and characterization of a novel trimethoprim-resistant dihydrofolate reductase from a nosocomial isolate of Staphylococcus aureus CM.S2 (IMCJ1454). Antimicrob Agents Chemother, 2005. 49(9): p. 3948-51.

[56] Kadlec, K. and S. Schwarz, Identification of a novel trimethoprim resistance gene, dfrK, in a methicillin-resistant Staphylococcus aureus ST398 strain and its physical linkage to the tetracycline resistance gene tet(L). Antimicrob Agents Chemother, 2009. 53(2): p. 776-8.

[57] Kadlec, K., et al., Unusual small plasmids carrying the novel resistance genes dfrK or apmA isolated from methicillin-resistant or -susceptible staphylococci. J Antimicrob Chemother, 2012. 67(10): p. 2342-5.

[58] Schwarz, S., et al., Plasmid-mediated antimicrobial resistance in staphylococci and other firmicutes. Microbiol Spectr, 2014. 2(6):PLAS-0020-2014.doi:10.1128/microbiolspec. PLAS-0020-2014

[59] Khan, S.A., Novick R., Terminal nucleotide sequences of Tn551, a transposon specifying erythromycin resistance in Staphylococcus aureus: homology with Tn3. Plasmid, 1980. 4: p. $148-54$.

[60] Leclercq, R., Courvalin, P., Bacterial resistance to macrolide, lincosamide, and streptogramin antibiotics by target modification. Antimicrob Agents Chemother, 1991. 35(7): p. $1267-72$.

[61] Trieu-Cuot P, Poyart-Salmeron C, Carlier C, Courvalin P. Molecular dissection of the transposition mechanism of conjugative transposons from Gram-positive cocci. In: Dunny G M, Patrick P, Cleary L L, editors. Genetics and molecular biology of streptococci, lactococci, and enterococci. Washington, D.C: American Society for Microbiology; 1991. pp. 21-27.

[62] Thakker-Varia, S., Jenssen, W.D., Moon-Mcdermott, L., Weinstein, M.P., Dubin, D.T., Molecular epidemiology of Macrolides-Lincosamides-Streptogramin B resistance in Staphylococcus aureus and Coagulase-Negative Staphylococci. Antimicrob Agents Chemother, 1987. 31(5): p. 735-43.

[63] Murphy, E., Nucleotide Sequence of ermA, a macrolide-lincosamide-streptogramin B determinant in Staphylococcus aureus. J Bacteriol, 1985. 162(2): p. 633-40.

[64] Chopra, I. and M. Roberts, Tetracycline antibiotics: mode of action, applications, molecular biology, and epidemiology of bacterial resistance. Microbiol Mol Biol Rev, 2001. 65(2): p. 232-60.

[65] Bismuth, R., Zilhao, R., Sakamoto, H., Guesdon, J., Courvalin, P, Gene heterogeneity for tetracycline resistance in Staphylococcus spp. Antimicrob Agents Chemother, 1990. 34(8): p. 1611-14. 
[66] Lyon, B.R., Skurray, R., Antimicrobial resistance of Staphylococcus aureus: genetic basis. Microbiol Rev, 1987. 51(1): p. 88-134.

[67] Tennent, J.M., May, J.W., Skurray, R.A., Characterisation of chloramphenicol resistance plasmids of Staphylococcus aureus and S. epidermidis by restriction enzyme mapping techniques. J Med Microbiol, 1986. 22: p. 79-84.

[68] Hershberger, E., Donabedian, S., Konstantinou, K., Zervos, M.J., Quinupristin-Dalfopristin resistance in Gram-Positive bacteria: mechanism of resistance and epidemiology. Clin Infect Dis, 2004. 38(92-98).

[69] Allignet, J., El Solh, N., Comparative analysis of staphylococcal plasmids carrying three streptogramin-resistance genes: vat-vgb-vga. Plasmid, 1999. 42: p. 134-138.

[70] Yazdankhah, S.P., et al., Fusidic acid resistance, mediated by fusB, in bovine coagulasenegative staphylococci. J Antimicrob Chemother, 2006. 58(6): p. 1254-1256.

[71] Hung, W.C., et al., Skin commensal staphylococci may act as reservoir for fusidic acid resistance genes. PLoS One, 2015. 10(11): p. e0143106.

[72] Lin, Y.T., et al., A novel staphylococcal cassette chromosomal element, SCCfusC, carrying fusC and speG in fusidic acid-resistant methicillin-resistant Staphylococcus aureus. Antimicrob Agents Chemother, 2014. 58(2): p. 1224-7.

[73] Holden, M.T., et al., Complete genomes of two clinical Staphylococcus aureus strains: evidence for the rapid evolution of virulence and drug resistance. Proc Natl Acad Sci U S A, 2004. 101(26): p. 9786-91.

[74] Ender, M., B. Berger-Bachi, and N. McCallum, Variability in SCCmecN1 spreading among injection drug users in Zurich, Switzerland. BMC Microbiol, 2007. 7: p. 62.

[75] Kinnevey, P.M., et al., Emergence of sequence type 779 methicillin-resistant Staphylococcus aureus harboring a novel pseudo staphylococcal cassette chromosome mec (SCCmec)SCC-SCCCRISPR composite element in Irish hospitals. Antimicrob Agents Chemother, 2013. 57(1): p. 524-31.

[76] Jevons, M., "Celbenin"-resistant staphylococci. Br Med J, 1961. 124: p. 124-5.

[77] Peacock, S., Paterson, GK., Mechanisms of methicillin resistance in Staphylococcus aureus. Annu Rev Biochem, 2015. 84: p. 577-601.

[78] Ito, T., Y. Katayama, and K. Hiramatsu, Cloning and nucleotide sequence determination of the entire mec DNA of pre-methicillin-resistant Staphylococcus aureus N315. Antimicrob Agents Chemother, 1999. 43(6): p. 1449-58.

[79] Katayama, Y., T. Ito, and K. Hiramatsu, A new class of genetic element, staphylococcus cassette chromosome mec, encodes methicillin resistance in Staphylococcus aureus. Antimicrob Agents Chemother, 2000. 44(6): p. 1549-55. 
[80] (IWG-SCC), I.W.G.o.t.C.o.S.C.C.E., Classification of staphylococcal cassette chromosome mec (SCCmec): guidelines for reporting novel SCCmec elements. Antimicrob Agents Chemother, 2009. 53(12): p. 4961-7.

[81] Kloos, W.E., Ballard, D.N., George, C.G., Webster, J.A., Hubner, R.J., Ludwig, W., Schleifer, K.H. Fiedler, F. and Schubert, K., Delimiting the genus Staphylococcus through description of Macrococcus caseolyticus gen. nov., comb. nov. and Macrococcus equipercicus sp. nov., and Macrococcus bovicus sp. nov. and Macrococcus carouselicus sp. nov. J Syst Bacteriol, 1998. 48: p. 859-77.

[82] Ito, T., Katayama, Y., Asada, K., Mori, N., Tsutsumimoto, K., Tiensasitorn, C., Hiramatsu, K., Structural Comparison of Three Types of Staphylococcal Cassette Chromosome mec Integrated in the Chromosome in Methicillin-Resistant Staphylococcus aureus. Antimicrob Agents Chemother, 2001. 45(5): p. 1323-36.

[83] Ito, T., Ma, XX., Takekuchi, F., Okuma, K., Yuzawa, H., Hiramatsu, K., Novel type V staphylococcal cassette chromosome mec driven by a novel cassette chromosome recombinase, ccrC. Antimicrob Agents Chemother, 2004. 48(7): p. 2637-51.

[84] Ma, X., Ito, T., Tiensasitorn, C., Jamklnag, M., Chongtrakool, P., Boyle-Vavra, S., Daum, R.S., Hiramatsu, K., Novel type of staphylococcal cassette chromosome mec identified in community-acquired methicillin-resistant Staphylococcus aureus strains. Antimicrob Agents Chemother, 2002. 46(4): p. 1147-52.

[85] Barbier, F., Ruppe, E., Hernandez, D., Lebaux, D., Methicillin-resistant coagulasenegative staphylococci in the community: high homology of SCCmec IVa between Staphylococcus epidermidis and major clones of methicillin-resistant Staphylococcus aureus. J Infect Dis, 2010. 202: p. 270-281.

[86] Bouchami, O., Ben Hassen, A., Lencastre, H., Miragaia, M., Molecular epidemiology of methicillin-resistant Staphylococcus hominis (MRSHo): low clonality and reservoirs of SCCmec structural elements. PLoS One, 2011. 6(7): p. e21940.

[87] Bouchami, O., Ben Hassen, A., Lencastre, H., Miragaia, M., High prevalence of mec complex C and ccrC is independent of SCCmec type V in Staphylococcus haemolyticus. Eur J Clin Microbiol Infect Dis, 2011. 31(4): p. 605-14.

[88] Schwarz, S., C. Werckenthin, and C. Kehrenberg, Identification of a plasmid-borne chloramphenicol-florfenicol resistance gene in Staphylococcus sciuri. Antimicrob Agents Chemother, 2000. 44(9): p. 2530-3.

[89] Murphy, E., L. Huwyler, and C. de Freire Bastos Mdo, Transposon Tn554: complete nucleotide sequence and isolation of transposition-defective and antibiotic-sensitive mutants. EMBO J, 1985. 4(12): p. 3357-65.

[90] Toh, S.M., et al., Acquisition of a natural resistance gene renders a clinical strain of methicillin-resistant Staphylococcus aureus resistant to the synthetic antibiotic linezolid. Mol Microbiol, 2007. 64(6): p. 1506-14. 
[91] Livermore, D.M., Linezolid in vitro: mechanism and antibacterial spectrum. J Antimicrob Chemother, 2003. 51(Suppl 2): p. ii9-16.

[92] Locke, J.B., M. Hilgers, and K.J. Shaw, Mutations in ribosomal protein L3 are associated with oxazolidinone resistance in staphylococci of clinical origin. Antimicrob Agents Chemother, 2009. 53(12): p. 5275-8.

[93] Sanchez Garcia, M., et al., Clinical outbreak of linezolid-resistant Staphylococcus aureus in an intensive care unit. JAMA, 2010. 303(22): p. 2260-4.

[94] Mendes, R.E., et al., First report of cfr-mediated resistance to linezolid in human staphylococcal clinical isolates recovered in the United States. Antimicrob Agents Chemother, 2008. 52(6): p. 2244-6.

[95] Kehrenberg, C. and S. Schwarz, Distribution of florfenicol resistance genes fexA and cfr among chloramphenicol-resistant Staphylococcus isolates. Antimicrob Agents Chemother, 2006. 50(4): p. 1156-63.

[96] Wang, Y., et al., Detection of the staphylococcal multiresistance gene cfr in Proteus vulgaris of food animal origin. J Antimicrob Chemother, 2011. 66(11): p. 2521-6.

[97] Wang, Y., et al., Detection of the staphylococcal multiresistance gene cfr in Macrococcus caseolyticus and Jeotgalicoccus pinnipedialis. J Antimicrob Chemother, 2012. 67(8): p. 1824-7.

[98] Liu, Y., et al., Transferable multiresistance plasmids carrying cfr in Enterococcus spp. from swine and farm environment. Antimicrob Agents Chemother, 2013. 57(1): p. 42-8.

[99] Shore, A.C., et al., Identification and characterization of the multidrug resistance gene cfr in a Panton-Valentine leukocidin-positive sequence type 8 methicillin-resistant Staphylococcus aureus IVa (USA300) isolate. Antimicrob Agents Chemother, 2010. 54(12): p. 4978-84.

[100] Klevens, R.M., et al., Invasive methicillin-resistant Staphylococcus aureus infections in the United States. JAMA, 2007. 298(15): p. 1763-71.

[101] Flamm, R.K., et al., An international activity and spectrum analysis of linezolid: ZAAPS Program results for 2011. Diagn Microbiol Infect Dis, 2013. 76(2): p. 206-13.

[102] Flamm, R.K., et al., Linezolid surveillance results for the United States: LEADER surveillance program 2011. Antimicrob Agents Chemother, 2013. 57(2): p. 1077-81.

[103] Baos, E., et al., Characterization and monitoring of linezolid-resistant clinical isolates of Staphylococcus epidermidis in an intensive care unit 4 years after an outbreak of infection by cfr-mediated linezolid-resistant Staphylococcus aureus. Diagn Microbiol Infect Dis, 2013. 76(3): p. 325-9.

[104] Gopegui, E.R., et al., Transferable multidrug resistance plasmid carrying cfr associated with tet(L), ant(4')-Ia, and dfrK genes from a clinical methicillin-resistant Staphylococcus aureus ST125 strain. Antimicrob Agents Chemother, 2012. 56(4): p. 2139-42. 
[105] Lozano, C., et al., Characterization of a cfr-positive methicillin-resistant Staphylococcus epidermidis strain of the lineage ST22 implicated in a life-threatening human infection. Diagn Microbiol Infect Dis, 2012. 73(4): p. 380-2.

[106] Fessler, A.T., et al., Cfr-mediated linezolid resistance in methicillin-resistant Staphylococcus aureus and Staphylococcus haemolyticus associated with clinical infections in humans: two case reports. J Antimicrob Chemother, 2014. 69(1): p. 268-70.

[107] Mendes, R.E., et al., Dissemination of a pSCFS3-like cfr-carrying plasmid in Staphylococcus aureus and Staphylococcus epidermidis clinical isolates recovered from hospitals in Ohio. Antimicrob Agents Chemother, 2013. 57(7): p. 2923-8.

[108] Bender, J., et al., Linezolid resistance in clinical isolates of Staphylococcus epidermidis from German hospitals and characterization of two cfr-carrying plasmids. J Antimicrob Chemother, 2015. 70(6): p. 1630-8. 
